\title{
The effect of electrode infiltration on the performance of tubular solid oxide fuel cells under electrolysis and fuel cell modes
}

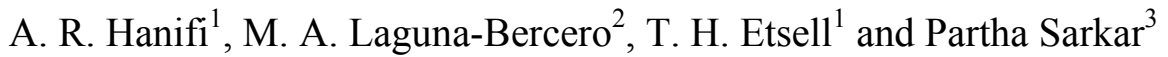 \\ ${ }^{1}$ Department of Chemical \& Materials Engineering, University of Alberta, Edmonton, Alberta \\ T6G 2V4, Canada \\ ${ }^{2}$ Instituto de Ciencia de Materiales de Aragón (ICMA), CSIC- Universidad de Zaragoza \\ C/ Pedro Cerbuna 12, E-50009, Zaragoza, Spain \\ ${ }^{3}$ Environment \& Carbon Management, Alberta Innovates - Technology Futures, Edmonton, \\ Alberta T6N 1E4, Canada
}

\begin{abstract}
The electrochemical performance of two different anode supported tubular cells (50:50 wt\% NiO:YSZ (yttria stabilized zirconia) as the fuel electrode and YSZ as the electrolyte) under SOFC (solid oxide fuel cell) and SOEC (solid oxide electrolysis cell) modes were studied in this research. LSM ( $\left.\mathrm{La}_{0.80} \mathrm{Sr}_{0.20} \mathrm{MnO}_{3-\delta}\right)$ was infiltrated into a thin porous YSZ layer to form the oxygen electrode of both cells and, in addition, $\mathrm{Ni}-\mathrm{SDC}\left(\mathrm{Sm}_{0.2} \mathrm{Ce}_{0.8} \mathrm{O}_{1.9}\right)$ was infiltrated into the fuel electrode of one of the cells. Microstructure of the infiltrated fuel cells showed a suitable distribution of fine LSM and SDC particles (50-100 nm) near the interface of electrodes and electrolyte and throughout the bulk of the electrodes. The results show that SDC infiltration not only enhances the electrochemical reaction in SOFC mode but improves the performance even more in SOEC mode. In addition, LSM infiltrated electrodes also boost the SOEC performance in comparison with standard LSM-YSZ composite electrodes, due to the well-dispersed LSM nanoparticles (favouring the electrochemical reactions) within the YSZ porous matrix.
\end{abstract}

Keywords: Microtubular, Infiltration, Ni-YSZ, SOFC, SOEC 


\section{Introduction}

The Ni-YSZ/YSZ/LSM-YSZ system, where Ni-YSZ forms the porous composite fuel electrode and LSM $\left(\mathrm{La}_{1-\mathrm{x}} \mathrm{Sr}_{\mathrm{x}} \mathrm{MnO}_{3-\delta}\right)$-YSZ the porous composite oxygen electrode, has been the most studied and fabricated SOFC system to date [1, 2]. Fabrication of a conventional Ni-YSZ fuel electrode requires high temperature sintering $\left(\sim 1400^{\circ} \mathrm{C}\right)$ and reduction $\left(900-1000^{\circ} \mathrm{C}\right)$ [3]. The LSM oxygen electrode is usually exposed to a lower sintering temperature (max. $1250^{\circ} \mathrm{C}$ ) to prevent reaction between YSZ and LSM which results in the formation of poorly conducting phases such as $\mathrm{La}_{2} \mathrm{Zr}_{2} \mathrm{O}_{7}$ and $\mathrm{SrZrO}_{3}$ [4]. The high temperature sintering of SOFC electrodes will eventually lead to significant grain growth and a corresponding loss of surface area and electrochemical activity in the electrode phases.

Infiltration/impregnation (of generally nitrates) has been established as an important method in the development of high performing electrodes giving them a suitable microstructure for oxygen reduction or fuel oxidation. Infiltration can enhance the catalytic activity (via fine dispersed particles), and ionic and/or electronic conductivity (via connected particles) of fuel cell electrodes leading to a cell power boost. In addition, the high active surface area of the infiltrated particles enables a reduced operating temperature, improving cell stability and reliability [5-7]. The lower particle size and higher surface activity of the infiltrates is a result of a comparatively low heat treatment temperature needed to decompose the nitrates and form the final phases versus the conventional high sintering temperatures for composite electrodes.

Infiltrating LSM into a porous YSZ structure has been previously carried out by various SOFC groups [8-13]. Improvement in the cell performance due to enhanced triple phase boundary (TPB) length and catalytic activity compared to the traditional composite LSM-YSZ 
cathode has been reported. Infiltration of a ceria-based catalyst into the Ni-YSZ anode also increases the TPBs for hydrogen oxidation and the ionic conductivity leading to improved electrode performance [14-17] as well as coverage of Ni particles by the infiltrate thereby lowering its sintering and agglomeration [3, 17]. Ceria infiltration has also been shown to improve sulphur tolerance of the Ni-YSZ anode to a significant extent [18].

An efficient and economic way for hydrogen production is to use a solid oxide electrolysis cell (SOEC). In fact an SOEC is a reversible fuel cell in which steam is fed to the cathode where it is converted to hydrogen fuel $[19,20]$. This method consumes much less electrical energy compared to conventional water electrolysis for the production of hydrogen. High temperature steam electrolysis has been recently demonstrated using microtubular cells [21-23]. Moreover, application of infiltrated electrodes for SOEC is a relatively new topic with few reported studies to date. More recently, Yang et al. [24] showed that LSM infiltrated porous YSZ has lower area specific resistance compared with a conventional LSM-YSZ composite electrode under SOEC mode testing. In addition, cells with LSM infiltrated electrodes have demonstrated stable performance under SOEC operation. Chen et al. [25] have shown that GDC impregnated LSM is an effective anode for high temperature SOECs. This same research group also showed that LSM infiltrated electrodes exhibited high electrocatalytic activity and good stability under SOEC operation conditions, and concluded that the high stability is related to the microstructural stability of infiltrated LSM nanoparticles due to the effect of LSM lattice shrinkage under SOEC polarization [26].

In addition, $\mathrm{Li}$ et al. [27] also reported on SOEC cells with Ni infiltrated composite cathodes based on LSCM $\left(\mathrm{La}_{0.75} \mathrm{Sr}_{0.25} \mathrm{Cr}_{0.5} \mathrm{Mn}_{0.5} \mathrm{O}_{3-\delta}\right)$. They found that the loading of $\mathrm{Ni}$ improves the current density by approximately $20 \%$ and, in addition, the combination of 
infiltrated nickel and redox-stable LSCM also improved the stability of the cathode. Finally, researchers from the Watanabe group prepared SOEC fuel electrodes using a highly dispersed nickel-SDC catalyst $[27,28]$. They found that the Ni-dispersed SDC fuel electrode gave the highest performance at 17 vol.\% of nickel loading due to effective enhancement of the reaction rate by increasing the active reaction sites and lowering the electronic resistance. The authors measured a cell consisting of Ni-dispersed SDC fuel electrode, ScSZ electrolyte, SDC interlayer and LSC as the oxygen electrode and obtained $1.13 \mathrm{~V}$ at $-0.5 \mathrm{~A} \mathrm{~cm}^{-2}$ and $900{ }^{\circ} \mathrm{C}$ under $60 \% \mathrm{RH}$ (relative humidity) of steam. From our knowledge, there is no report in the literature about the effect of ceria infiltrated nanoparticles into the fuel electrode for electrolysis applications.

In this manuscript, the effects on the electrochemical performance of tubular fuel cells of LSM ( $\left(\mathrm{La}_{0.80} \mathrm{Sr}_{0.20} \mathrm{MnO}_{3-\delta}\right)$ infiltration into porous $\mathrm{YSZ}$ at the oxygen electrode and, in addition, SDC $\left(\mathrm{Sm}_{0.2} \mathrm{Ce}_{0.8} \mathrm{O}_{1.9}\right)$ infiltration into the Ni-YSZ fuel electrode, are studied in both SOFC and SOEC modes.

\section{Experimental procedure}

The anode supported cells studied in this paper were fabricated by slip casting of a NiOYSZ anode support followed by dip coating of a thin YSZ electrolyte and a thin porous YSZ layer for cathode infiltration. LSM was infiltrated into the thin porous YSZ layer of both cells to form the cathode and SDC was infiltrated into the NiO-YSZ anode support of the second cell.

In order to produce a suitable slip for casting the anode supported cells, YSZ powder (TZ-8Y, $8 \mathrm{~mol} \% \mathrm{Y}_{2} \mathrm{O}_{3}$, Tosoh) was calcined at $1500^{\circ} \mathrm{C}$ for $3 \mathrm{~h}$, cooled and mixed with $50 \mathrm{wt} \%$ $\mathrm{NiO}$ powder (Baker Chemicals) and water at a powder:water ratio of 1:1. The mixture was then milled at $120 \mathrm{rpm}$ for $72 \mathrm{~h}$ in a plastic bottle with $5 \mathrm{~mm}$ zirconia balls. Additional water was added after milling to adjust the solid loading of the final suspension to $40 \%$. The $\mathrm{pH}$ of the slip 
was set to 4.0 using $2 \%$ hydrochloric acid. In order to generate high porosity, 30 vol. $\%$ graphite (Sigma Aldrich $<325$ mesh) was incorporated into the slip following $\mathrm{pH}$ adjustment, and then the suspension was mixed for 15 minutes prior to slip casting.

To create the tubular support, the slip was cast into a plaster mold (previously prepared from a tubular mandrel) and left for about 1 minute, after which the excess slip was quickly poured out. The wet tube was then dried at room temperature for $1 \mathrm{~h}$. The resulting drying shrinkage facilitates removal of the green tube. The green tube was dried at $100^{\circ} \mathrm{C}$ in an oven, heated at $700^{\circ} \mathrm{C}$ for $1 \mathrm{~h}$ to oxidize all the graphite, and then pre-sintered under air at $1150^{\circ} \mathrm{C}$ for $3 \mathrm{~h}$. Further details regarding the fabrication of thin porous supports via slip casting and the parameters affecting tube thickness during casting are discussed elsewhere [29, 30].

The electrolyte and the thin porous YSZ layer formulas and dip coating procedure are explained in [31] and [31, 32], respectively. The $\operatorname{LSM}\left(\mathrm{La}_{0.80} \mathrm{Sr}_{0.20} \mathrm{MnO}_{3-\delta}\right.$ cathode and also SDC $\left(\mathrm{Sm}_{0.2} \mathrm{Ce}_{0.8} \mathrm{O}_{1.9}\right)$ infiltration methods are addressed in [32]. In this manuscript the anode supported cells without and with SDC infiltrated are referred to as "Tube 1" and "Tube 2", respectively.

For the electrochemical experiments, platinum mesh was tightly placed inside the tube to provide electrical contact between the fuel electrode and the Pt lead wire. Pt wires were used for current collection at the oxygen electrode side, and LSM paste (terpineol-based) was used to improve current collection. Subsequently, the cell and electrical leads were placed inside a small tubular furnace. The active area of the cell was limited to $\sim 2 \mathrm{~cm}^{2}$ in order to be sure of a homogeneous temperature over the cell active area. This temperature was displayed by a thermocouple placed next to the oxygen electrode of the cell. 
Fuel gas (steam and hydrogen mixtures) was introduced into the anode tube through an alumina tube sealed to the open side of the tubular cell using a ceramic paste. Steam was supplied by the use of a direct vapour humidifier controlling the relative humidity $(\% \mathrm{RH})$ with a resolution of $\pm 1.3 \%$. All gas lines located downstream of the humidifier were externally heated in order to prevent steam condensation.

Electrochemical measurements were performed using a Zahner Zennium (ZAHNERElektrik GmbH \& Co. KG, Germany) electrochemical workstation. j-V (current density-voltage) curves were collected in potentiodynamic mode from OCV (open circuit voltage) down to $0.5 \mathrm{~V}$ in SOFC mode, and from OCV up to $1.5 \mathrm{~V}$ in SOEC mode, using a scan rate of $5 \mathrm{mV} \mathrm{s}^{-1}$. Electrochemical impedance spectroscopy (EIS) measurements were performed using a sinusoidal amplitude signal of $20 \mathrm{mV}$ in the frequency range of $100 \mathrm{kHz}$ to $0.1 \mathrm{~Hz}$.

Finally, post-mortem microstructural cell analysis was performed using a JEOL 6301F scanning electron microscope (SEM).

\section{Results and discussion}

\section{Microstructural change upon infiltration}

\subsection{SDC infiltration}

Following SDC infiltration into the fuel electrode of Tube 2 having about 50 vol.\% open porosity, $10 \%$ weight gain was recorded after decomposing the nitrates. This suggests that the YSZ:SDC:Ni ratio in the cell following the complete infiltration procedure was 59:11:30 vol.\%. SDC infiltration leads to a small $5 \%$ decrease in the overall porosity of the support to 45 vol.\% indicating that sufficient porosity remains for gas diffusion and removal of reaction products or increasing the infiltrate content. 


\subsection{LSM infiltration}

Weight gain of the thin porous YSZ layer upon LSM infiltration is estimated to be 30 $\mathrm{wt} \%$ which leads to an YSZ:LSM ratio of $72: 28$ vol. $\%$ and results in a $14 \%$ decrease in total open porosity from $50 \%$ to $36 \%$.

\section{Electrochemical characterization}

\section{1. $j$-V experiments in fuel cell and electrolysis mode}

Electrochemical studies for both Tube 1 and Tube 2 were performed in SOFC and SOEC operation modes. In figure 1 we can observe the $j$-V curves for Tube $1(\mathrm{Ni} / \mathrm{YSZ}-\mathrm{YSZ}-\mathrm{LSM} / \mathrm{YSZ}$ cell) collected at $800{ }^{\circ} \mathrm{C}$ under different fuel conditions. Details about fuel conditions, OCV (open circuit voltage) values and ASR (area specific resistance) values are summarized in table 1. Under favourable SOFC conditions (pure hydrogen), we have obtained ASR values in fuel cell mode of about $0.7 \Omega \mathrm{cm}^{2}$ at $800{ }^{\circ} \mathrm{C}$, in concordance with cells fabricated using the same procedure [33]. In SOEC mode, concentration polarization is clearly observed even at low current densities at the low steam content $\left(5 \% \mathrm{H}_{2} \mathrm{O}\right)$. However, when increasing the steam content in the fuel $\left(30 \% \mathrm{H}_{2} \mathrm{O}-70 \% \mathrm{H}_{2}\right)$, concentration polarization disappears and similar ASR values are obtained in both modes of operation (see table 1), demonstrating the reversibility of Tube 1 .

Under more favourable electrolysis fuel conditions $\left(50 \% \mathrm{H}_{2} \mathrm{O}-50 \% \mathrm{H}_{2}\right)$, the performance in SOEC mode is enhanced. In figure 2 we can observe the effect of temperature ( 750,800 and $850{ }^{\circ} \mathrm{C}$ ) using $50 \%$ steam on SOEC performance. For this set of experiments, minor data fluctuations are noticeable associated with an experimental problem of steam condensation along the gas pipe lines thus affecting adequate inner current collection. OCV values are in 
agreement with those predicted using the Nernst equation, and also ASR values decreased upon increasing the temperature, as observed in table 1.

In order to study the influence of LSM infiltrated electrodes, these results are compared with the performance of cells with identical composition (Ni/YSZ-YSZ-LSM/YSZ cell) fabricated by traditional methods [23]. For the same fuel composition (using $50 \%$ steam) they reported ASR values of $1.1 \Omega \mathrm{cm}^{2}$ at $750{ }^{\circ} \mathrm{C}$, whereas with the infiltrated cell the ASR value only slightly decreased to $1.08 \Omega \mathrm{cm}^{2}$. However, this enhancement is much more noticeable when increasing the temperature $\left(0.7 \Omega \mathrm{cm}^{2}\right.$ at $820{ }^{\circ} \mathrm{C}$ for the standard cell vs. $0.49 \Omega \mathrm{cm}^{2}$ at $800{ }^{\circ} \mathrm{C}$ for the infiltrated cell). It is believed that the reason for this enhancement is due to an increase of TPB length for the infiltrated cell compared with the standard LSM-YSZ composite owing to the fine size of the dispersed LSM particles having a high active surface area. It is well known that LSM activates above $800^{\circ} \mathrm{C}$, especially under cathodic polarization [*]. In addition, Zhen et al. performed experiments at $900{ }^{\circ} \mathrm{C}$ and reported that the addition/impregnation of ionic conducting phases such as YSZ and GDC not only enhances the three phase boundary but also significantly promotes the surface exchange processes for the $\mathrm{O}_{2}$ reduction reaction on the LSM-based composite cathodes [**]. The combination of the LSM activation above $800{ }^{\circ} \mathrm{C}$ and the appropriate microstructure (fine dispersed particles) is probably the reason for the enhancement observed above $800{ }^{\circ} \mathrm{C}$.

In figure 3, $j$-V experiments for Tube $2(\mathrm{Ni} / Y S Z / S D C-Y S Z-L S M / Y S Z$ cell) using a fuel composition of $50 \% \mathrm{H}_{2} \mathrm{O}-50 \% \mathrm{H}_{2}$ are shown in both fuel cell and electrolysis modes as a function of temperature. As expected, ASR values also decreased when increasing the operating temperature, and experimental OCV values are in concordance with theoretical Nernst values, as observed in table 1 . If we analyse the ASR values obtained from the $j-\mathrm{V}$ experiments shown in 
table 1, it is quite remarkable that lower resistances are obtained in SOEC mode in comparison with SOFC mode for each studied temperature. It is well known that SDC infiltrated nanoparticles at the fuel electrode enhance hydrogen oxidation and thus also enhance the electrochemical performance of the cell in SOFC mode [7, 34], but this enhancement seems to be more noticeable under SOEC mode. Recent studies have shown that for this type of electrode with well-defined geometries and interfaces, the near-equilibrium $\mathrm{H}_{2}$ oxidation reaction pathway is dominated by electrocatalysis at the oxide/gas interface with minimal contributions from the oxide/metal/gas triple-phase boundaries [35]. In addition, it has also been recently shown that nonstoichiometric ceria leads to high efficiency energy conversion for dissociating $\mathrm{H}_{2} \mathrm{O}$ and $\mathrm{CO}_{2}$ to produce $\mathrm{H}_{2}$ and $\mathrm{CO}$ [36]. According to our results for Tube 2, SDC infiltrated nanoparticles are clearly catalysing the hydrogen formation reaction in SOEC mode.

\subsection{AC impedance measurements under current load}

EIS measurements under SOEC polarization were performed for both Tube 1 and Tube 2 at 750,800 and $850^{\circ} \mathrm{C}$ with a bias potential of $\mathrm{OCV}+0.5 \mathrm{~V}$, as shown in figure 4 . Experimental data were fitted using the following equivalent circuit: $L R_{e}\left(R_{1}, \mathrm{CPE} 1\right)\left(R_{2}, \mathrm{CPE} 2\right)\left(R_{3}, \mathrm{CPE} 3\right)$. For the fitting of EIS data at 800 and $850{ }^{\circ} \mathrm{C}, R_{3}$ was fitted to values close to zero, and as a consequence the third $\left(R_{3}\right.$, CPE3) contribution was removed from the model. Resistance fitting parameters are summarized in table 2. Although impedance analysis of these cells is rather complex, several findings are obtained from the fitting of the EIS data shown in figure 4.

Based on previous EIS analysis of similar microtubular cells [37], and also according to their characteristic frequencies and capacitance values, $R_{1}$ is typically associated with the electrochemical reactions at both fuel and oxygen electrodes (activation) (appearing at 2500 - 
$4000 \mathrm{~Hz}$ with capacitances of about $10^{-4} \mathrm{~F}$ ), and $R_{2}$ is normally associated with gas diffusion, especially at the fuel electrode (appearing at $\sim 10-40 \mathrm{~Hz}$ with capacitances of about $10^{-3} \mathrm{~F}$ ). The additional $R_{3}$ component, appearing at very low frequencies $(0.2 \mathrm{~Hz})$ and only present at the lower temperature $\left(750^{\circ} \mathrm{C}\right)$, will possibly be related to the presence of SDC nanoparticles at the fuel electrode, as this is the only difference between Tube 1 and Tube 2 . It seems that the catalytic effect of the SDC particles is much more noticeable at $750{ }^{\circ} \mathrm{C}$, and becomes less significant at $800-850{ }^{\circ} \mathrm{C}$, where similar ASR values are obtained for both cells. According to these experiments, it seems that SDC nanoparticles at the fuel electrode did not play any significant role at $800-850{ }^{\circ} \mathrm{C}$. In addition, there is another significant difference between Tube 1 and Tube 2 according to EIS data. As shown in table 2, if we compare $R_{1}$ and $R_{2}$ values for Tube 1 and Tube 2, there is a significant decrease in the $R_{1}$ value for Tube 2, whereas for the same cell the $R_{2}$ value increases when compared with Tube 1 . These observations are consistent with the assignment of $R_{1}$ to electrode activation and $R_{2}$ to diffusion principally at the fuel electrode, as the SDC nanoparticles in Tube 2 favour the activation for $\mathrm{H}_{2}$ formation at the fuel electrode but, at the same time, could slightly complicate gas channel flow for steam diffusion through the electrode.

\section{Microstructural analysis after the electrochemical studies}

Using the SEM after electrochemical studies, the thickness of the fuel electrode, electrolyte and oxygen electrode for both cells were estimated to be about 550,11 and $19 \mu \mathrm{m}$, respectively. Figure 5a represents the interface between the whole oxygen electrode thickness, electrolyte, and part of Tube 2. SDC particles (50-100 nm) show excellent coverage on YSZ in the vicinity of the electrolyte (Figure 5b, c). YSZ particles are also well covered by SDC within the bulk of the fuel electrode. It should be noted that infiltrated SDC improves the overall cell 
ionic conductivity and improves the TPB length. SDC can also form electronic bridging between unconnected Ni particles since doped ceria shows significant electronic conductivity under a reducing atmosphere [38]. This now involves isolated Ni particles in the overall fuel electrode electronic conduction. Fine LSM particle $(50-100 \mathrm{~nm})$ distribution on YSZ surfaces near the interface of electrolyte and oxygen electrode shown in Figure $5 \mathrm{~d}$ is similar to the microstructures previously shown by Sholklapper et al. $[10,11]$.

The distribution of LSM and SDC particles within both electrodes provides a high catalytic activity favouring the electrochemical reactions and a suitable current path. Based on the authors' previous experience on electrode infiltration, no microstructural changes are observed following testing and the nanoparticles (SDC at the fuel electrode and LSM at the oxygen electrode) remain unaltered.

\section{Conclusions}

Both LSM and SDC infiltrates are present as fine particles $(50-100 \mathrm{~nm})$ which are homogeneously distributed within the bulk as well as the interface of the electrodes and electrolyte. Following infiltration, sufficient porosity remains in the anode and cathode of the cells for gas diffusion. The results show that LSM infiltration at the oxygen electrode enhances the performance of the cells in comparison with standard cells using LSM-YSZ composite electrodes. At $750{ }^{\circ} \mathrm{C}$ using $50 \%$ steam, an ASR of $1.08 \Omega \mathrm{cm}^{2}$ was measured. Additional SDC infiltration into the porous Ni-YSZ electrode also improves the SOEC performance, especially at the lower temperature measured $\left(750{ }^{\circ} \mathrm{C}\right)$, where an ASR of $0.54 \Omega \mathrm{cm}^{2}$ was obtained using $50 \%$ steam.

\section{Acknowledgements:}


Part of the research carried out in Canada was supported through funding to the NSERC Solid Oxide Fuel Cell Canada Strategic Research Network from the Natural Sciences and Engineering Research Council (NSERC) and other sponsors listed at www.sofccanada.com. MAL-B acknowledges grant MAT2012-30763 financed by the Spanish Government (Ministerio de Ciencia e Innovación) and Feder program of the European Community, and also grant GA-LC035/2012, financed by the Aragón Government and La Caixa Foundation.

\section{References:}

[1] N.Q. Minh, Ceramic fuel-cells, Journal of the American Ceramic Society 76 (1993) 563.

[2] S.M. Haile, Fuel cell materials and components, Acta Materialia 51 (2003) 5981.

[3] S.P. Jiang, Y.Y. Duan, J.G. Love, Fabrication of high-performance NiO- $\mathrm{Y}_{2} \mathrm{O}_{3}-\mathrm{ZrO}_{2}$ cermet anodes of solid oxide fuel cells by ion impregnation, Journal of the Electrochemical Society 149 (2002) A1175.

[4] Y.J. Leng, S.H. Chan, K.A. Khor, S.P. Jiang, Development of LSM/YSZ composite cathode for anode-supported solid oxide fuel cells, Journal of Applied Electrochemistry 34 (2004) 409.

[5] T.Z. Sholklapper, C.P. Jacobson, S.J. Visco, L.C. De Jonghe, Synthesis of dispersed and contiguous nanoparticles in solid oxide fuel cell electrodes, Fuel Cells 8 (2008) 303.

[6] S.P. Jiang, A review of wet impregnation - An alternative method for the fabrication of high performance and nano-structured electrodes of solid oxide fuel cells, Materials Science and Engineering A-Structural Materials Properties Microstructure and Processing 418 (2006) 199.

[7] S.P. Jiang, Nanoscale and nano-structured electrodes of solid oxide fuel cells by infiltration: advances and challenges, International Journal of Hydrogen Energy 37 (2012) 449.

[8] Y. Huang, J.M. Vohs, R.J. Gorte, SOFC cathodes prepared by infiltration with various LSM precursors, Electrochemical and Solid State Letters 9 (2006) A237.

[9] Y.Y. Huang, J.M. Vohs, R.J. Gorte, Characterization of LSM-YSZ composites prepared by impregnation methods, Journal of the Electrochemical Society 152 (2005) A1347.

[10] T.Z. Sholklapper, V. Radmilovic, C.P. Jacobson, S.J. Visco, L.C. De Jonghe, Synthesis and stability of a nanoparticle-infiltrated solid oxide fuel cell electrode, Electrochemical and Solid State Letters 10 (2007) B74.

[11] T.Z. Sholklapper, C. Lu, C.P. Jacobson, S.J. Visco, L.C. De Jonghe, LSM-infiltrated solid oxide fuel cell cathodes, Electrochemical and Solid State Letters 9 (2006) A376.

[12] C. Lu, T.Z. Sholklapper, C.P. Jacobson, S.J. Visco, L.C. De Jonghe, LSM-YSZ cathodes with reaction-infiltrated nanoparticles, Journal of the Electrochemical Society 153 (2006) A1115.

[13] S.P. Jiang, Y.J. Leng, S.H. Chan, K.A. Khor, Development of ( $\mathrm{La}, \mathrm{Sr}) \mathrm{MnO}_{3}$-based cathodes for intermediate temperature solid oxide fuel cells, Electrochemical and Solid State Letters 6 (2003) A67.

[14] T.Z. Sholklapper, H. Kurokawa, C.P. Jacobson, S.J. Visco, L.C. De Jonghe, Nanostructured solid oxide fuel cell electrodes, Nano Letters 7 (2007) 2136. 
[15] J.S. Qiao, K.N. Sun, N.Q. Zhang, B. Sun, J.R. Kong, D.R. Zhou, Ni/YSZ and Ni-CeO $\mathrm{C}_{2} / \mathrm{YSZ}$ anodes prepared by impregnation for solid oxide fuel cells, Journal of Power Sources 169 (2007) 253.

[16] S.P. Jiang, S. Zhang, Y.D. Zhen, A.P. Koh, Performance of GDC-impregnated Ni anodes of SOFCs, Electrochemical and Solid State Letters 7 (2004) A282.

[17] T. Klemenso, K. Thyden, M. Chen, H.-J. Wang, Stability of Ni-yttria stabilized zirconia anodes based on Ni-impregnation, Journal of Power Sources 195 (2010) 7295.

[18] H. Kurokawa, T.Z. Sholklapper, C.P. Jacobson, L.C. De Jonghe, S.J. Visco, Ceria nanocoating for sulfur tolerant Ni-based anodes of solid oxide fuel cells, Electrochemical and Solid State Letters 10 (2007) B135.

[19] M. Ni, M.K.H. Leung, D.Y.C. Leung, Technological development of hydrogen production by solid oxide electrolyzer cell (SOEC), International Journal of Hydrogen Energy 33 (2008) 2337.

[20] M.A. Laguna-Bercero, Recent advances in high temperature electrolysis using solid oxide fuel cells: A review, Journal of Power Sources 203 (2012) 4.

[21] S. Hashimoto, Y. Liu, M. Mori, Y. Funahashi, Y. Fujishiro, Study of steam electrolysis using a microtubular ceramic reactor, International Journal of Hydrogen Energy 34 (2009) 1159.

[22] M.A. Laguna-Bercero, R. Campana, A. Larrea, J.A. Kilner, V.M. Orera, Steam electrolysis using a microtubular solid oxide fuel cell, Journal of the Electrochemical Society 157 (2010) B852.

[23] M.A. Laguna-Bercero, R. Campana, A. Larrea, J.A. Kilner, V.M. Orera, Performance and aging of microtubular YSZ-based solid oxide regenerative fuel cells, Fuel Cells 11 (2011) 116.

[24] C.H. Yang, C. Jin, A. Coffin, F.L. Chen, Characterization of infiltrated $\left(\mathrm{La}_{0.75} \mathrm{Sr}_{0.25}\right)_{0.95} \mathrm{MnO}_{3}$ as oxygen electrode for solid oxide electrolysis cells, International Journal of Hydrogen Energy 35 (2010) 5187.

[25] K.F. Chen, N. Ai, S.P. Jiang, Development of (Gd,Ce) $\mathrm{O}_{2}$-Impregnated (La,Sr) $\mathrm{MnO}_{3}$ anodes of high temperature solid oxide electrolysis cells, Journal of the Electrochemical Society 157 (2010) P89.

[26] K. Chen, N. Ai, S.P. Jiang, Reasons for the high stability of nano-structured ( $\mathrm{La}, \mathrm{Sr}) \mathrm{MnO}_{3}$ infiltrated $\mathrm{Y}_{2} \mathrm{O}_{3}-\mathrm{ZrO}_{2}$ composite oxygen electrodes of solid oxide electrolysis cells, Electrochemistry Communications 19 (2012) 119.

[27] H. Uchida, N. Osada, M. Watanabe, High-performance electrode for steam electrolysis mixed conducting ceria-based cathode with highly-dispersed Ni electrocatalysts, Electrochemical and Solid State Letters 7 (2004) A500.

[28] N. Osada, H. Uchida, M. Watanabe, Polarization behavior of SDC cathode with highly dispersed Ni catalysts for solid oxide electrolysis cells, Journal of the Electrochemical Society 153 (2006) A816.

[29] A.R. Hanifi, A. Torabi, T.H. Etsell, L. Yamarte, P. Sarkar, Porous electrolyte-supported tubular micro-SOFC design, Solid State Ionics 192 (2011) 368.

[30] A.R. Hanifi, A. Torabi, A. Shinbine, T.H. Etsell, P. Sarkar, Fabrication of thin porous electrolyte-supported tubular fuel cells using slip casting, Journal of Ceramic Processing Research 12 (2011) 336.

[31] A.R. Hanifi, A. Torabi, M. Zazulak, T.H. Etsell, L. Yamarte, P. Sarkar, T.M. C., Improved redox and thermal cycling resistant tubular ceramic fuel cells, ECS Transaction, 35(2011) 409. 
[32] K.S. Howe, A.R. Hanifi, K. Kendall, M. Zazulak, T.H. Etsell, P. Sarkar, Performance of microtubular SOFCs with infiltrated electrodes under thermal cycling, International Journal of Hydrogen Energy 38 (2013) 1058.

[33] A. Torabi, A.R. Hanifi, T.H. Etsell, P. Sarkar, The influence of porous support morphology on the electrochemical performance of solid oxide fuel cells, ECS Transaction, 35(2011) 499.

[34] R.J. Gorte, J.M. Vohs, Catalysis in Solid Oxide Fuel Cells, in: J.M. Prausnitz (Ed.) Annual Review of Chemical and Biomolecular Engineering, Vol. 2, , 2011, pp. 9.

[35] W.C. Chueh, Y. Hao, W. Jung, S.M. Haile, High electrochemical activity of the oxide phase in model ceria-Pt and ceria-Ni composite anodes, Nature Materials 11 (2012) 155.

[36] W.C. Chueh, C. Falter, M. Abbott, D. Scipio, P. Furler, S.M. Haile, A. Steinfeld, High-Flux Solar-driven thermochemical dissociation of $\mathrm{CO}_{2}$ and $\mathrm{H}_{2} \mathrm{O}$ using nonstoichiometric ceria, Science 330 (2010) 1797.

[37] M. Laguna-Bercero, A. Férriz, A. Larrea, L. Correas, V. Orera, Long-Term Stability Studies of Anode-Supported Microtubular Solid Oxide Fuel Cells, Fuel Cells (2013) In press.

[38] M. Mogensen, N.M. Sammes, G.A. Tompsett, Physical, chemical and electrochemical properties of pure and doped ceria, Solid State Ionics 129 (2000) 63.

Figures captions:

Figure 1. $j-\mathrm{V}$ experiments performed at SOFC and SOEC modes under different fuel conditions at $800{ }^{\circ} \mathrm{C}$ for Tube 1 .

Figure 2. Electrolysis experiments performed using $50 \% \mathrm{H}_{2} \mathrm{O}-50 \% \mathrm{H}_{2}$ as the fuel for Tube 1 .

Figure 3. SOFC and SOEC experiments performed using $50 \% \mathrm{H}_{2} \mathrm{O}-50 \% \mathrm{H}_{2}$ as the fuel for Tube 2.

Figure 4. EIS measurements under SOEC polarization using a bias potential of $+0.5 \mathrm{~V}$ at 750 , 800 and $850^{\circ} \mathrm{C}$ for (a) Tube 1 and (b) Tube 2.

Figure 5. SEM images showing the microstructure of Tube 2. (a): Interface between cathode, electrolyte and the anode, (b and c): YSZ coverage by SDC near the interface of the anode and electrolyte, (d): YSZ coverage by LSM near the interface of the oxygen electrode and electrolyte. 
Tables captions:

Table 1. Summary of the SOFC and SOEC experiments for Tube 1 and Tube 2. ASR values are calculated from the linear range of the $j$ - $\mathrm{V}$ experiments.

Table 2. Resistance values obtained by fitting EIS experimental data for Tube 1 and Tube 2 measured using $50 \% \mathrm{H}_{2} \mathrm{O}-50 \% \mathrm{H}_{2}$ as the fuel.

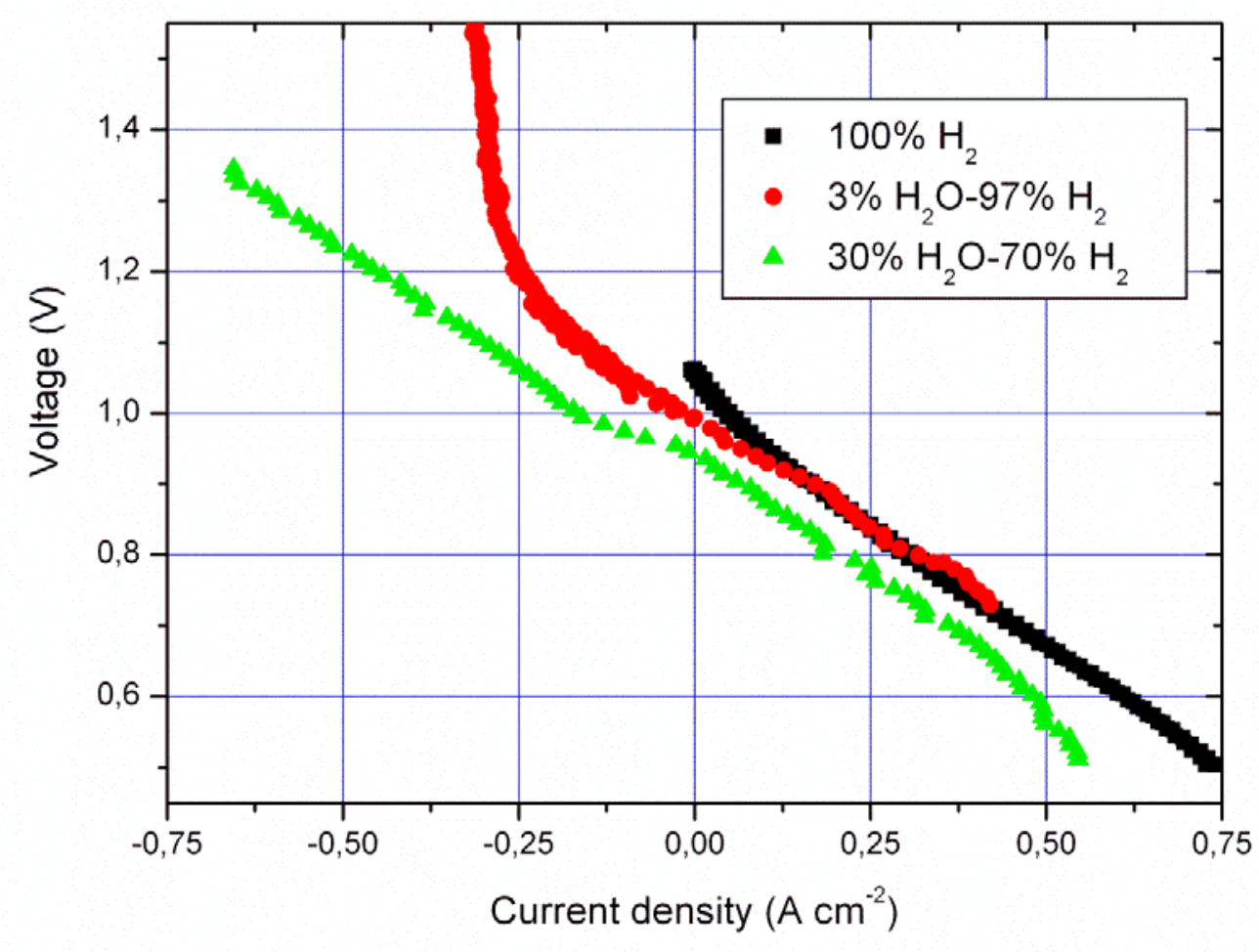

Figure 1. 


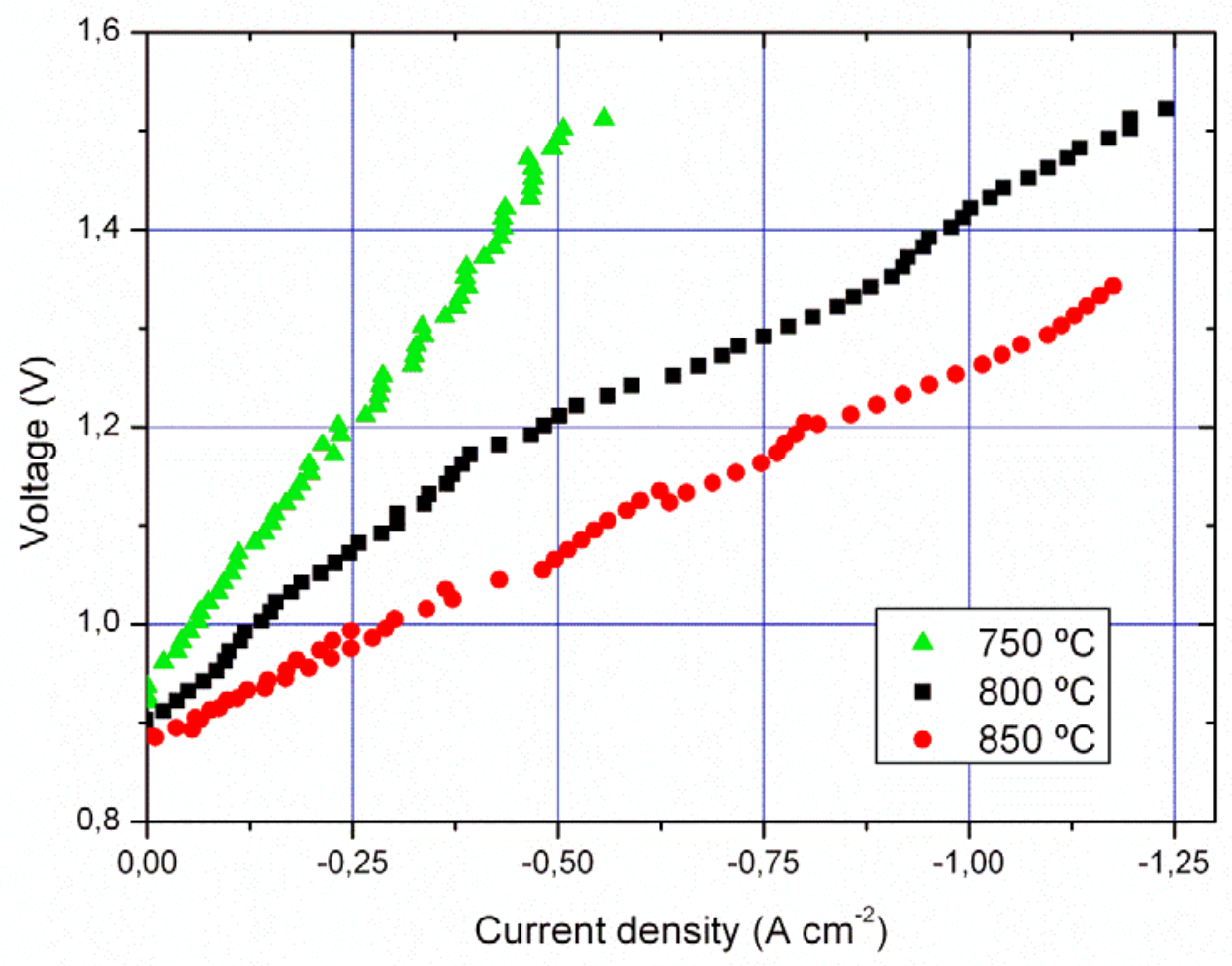

Figure 2. 


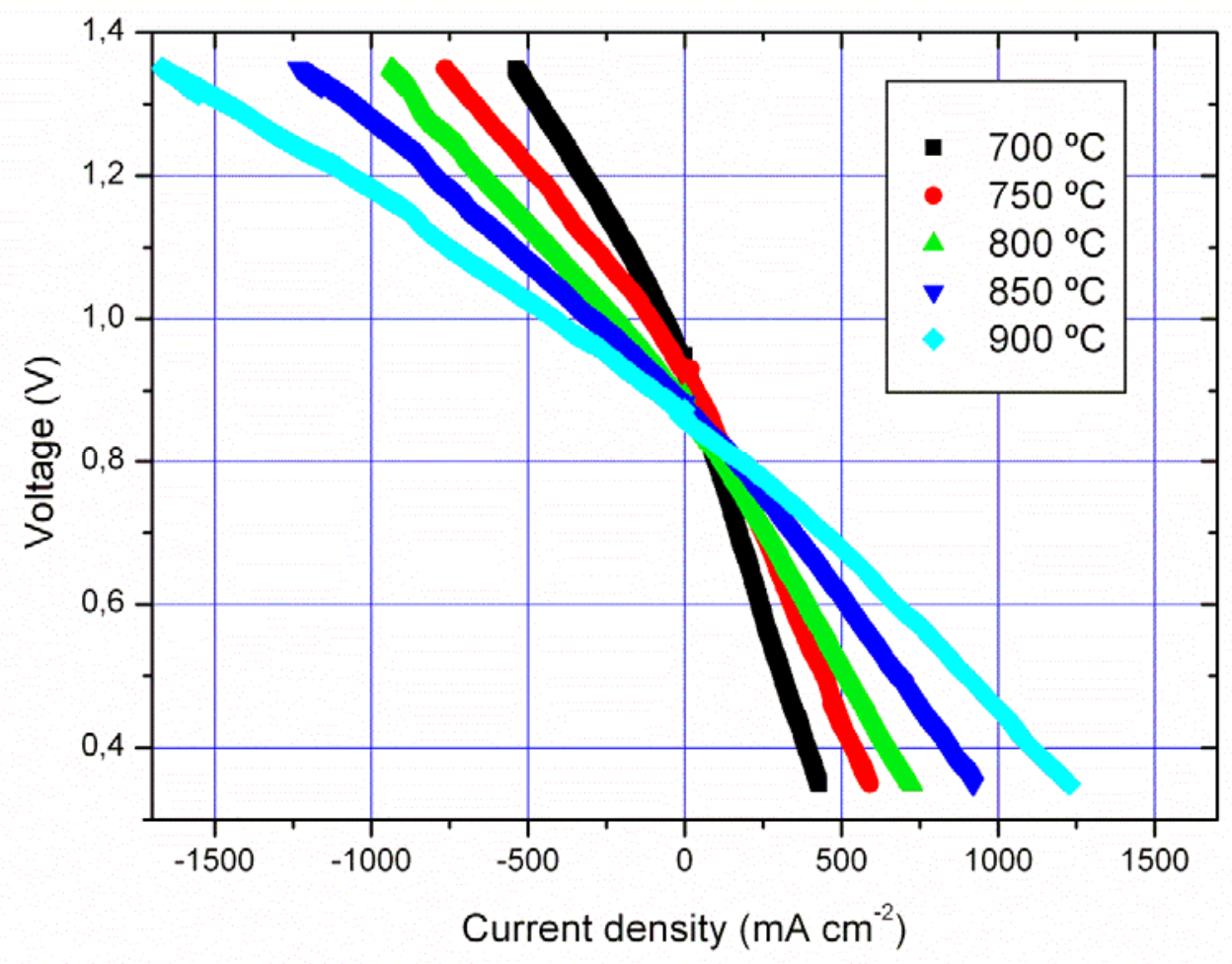

Figure 3. 


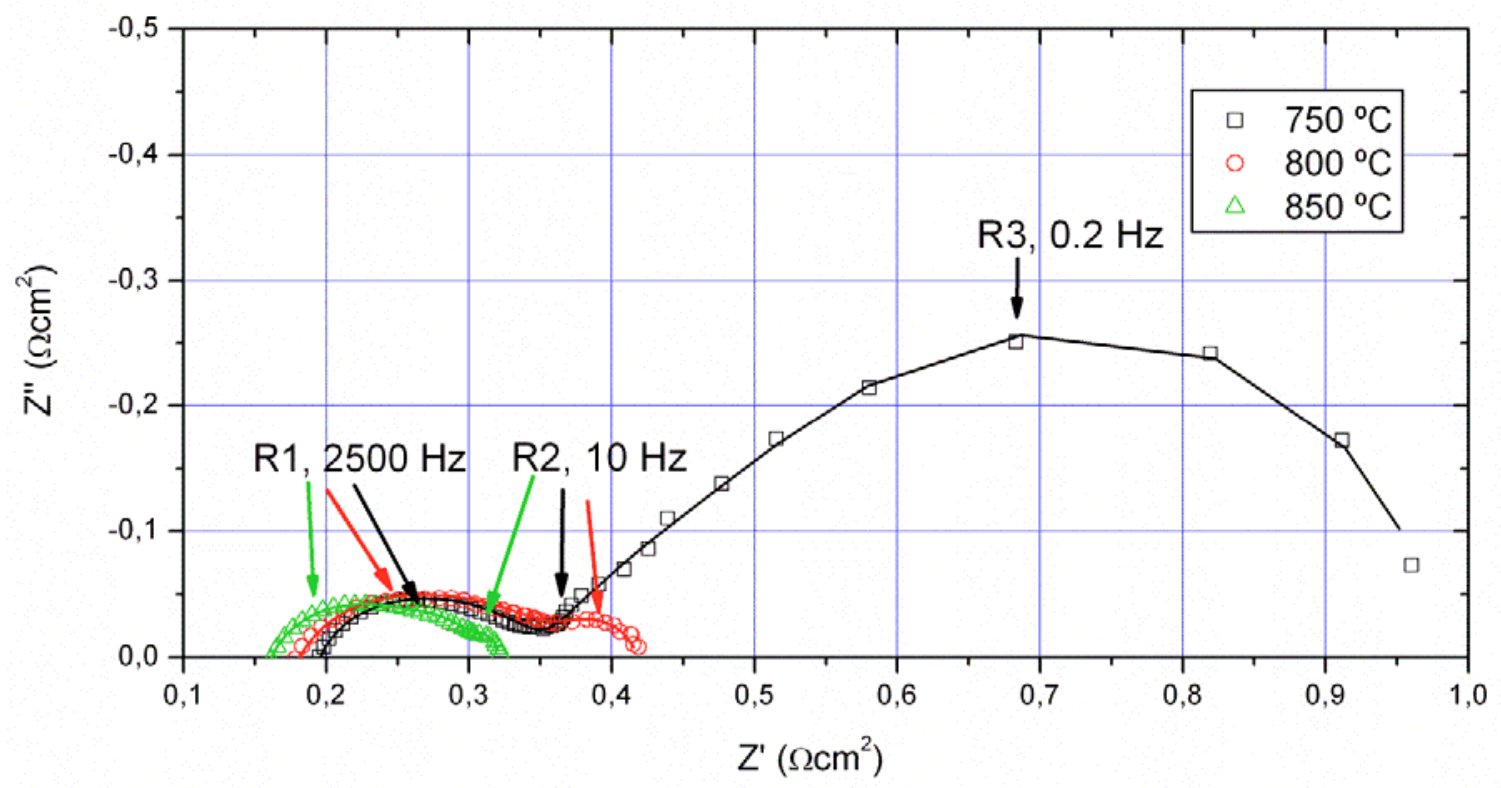

Figure 4a. 


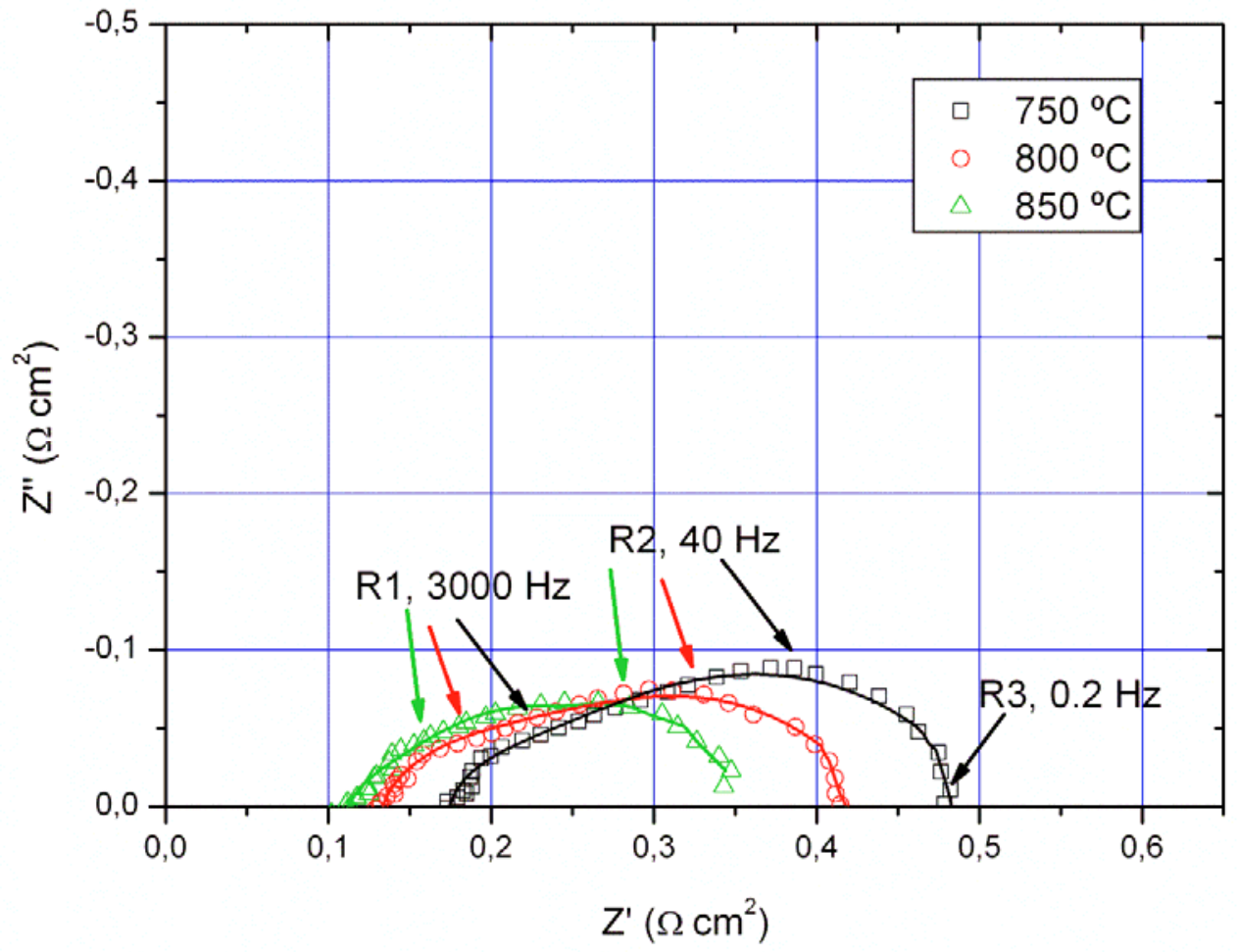

Figure $4 b$. 


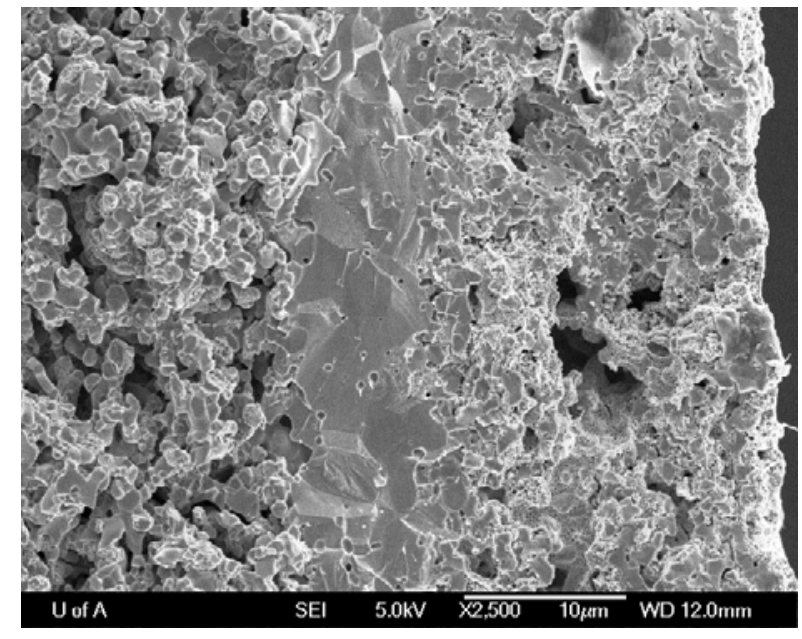

a

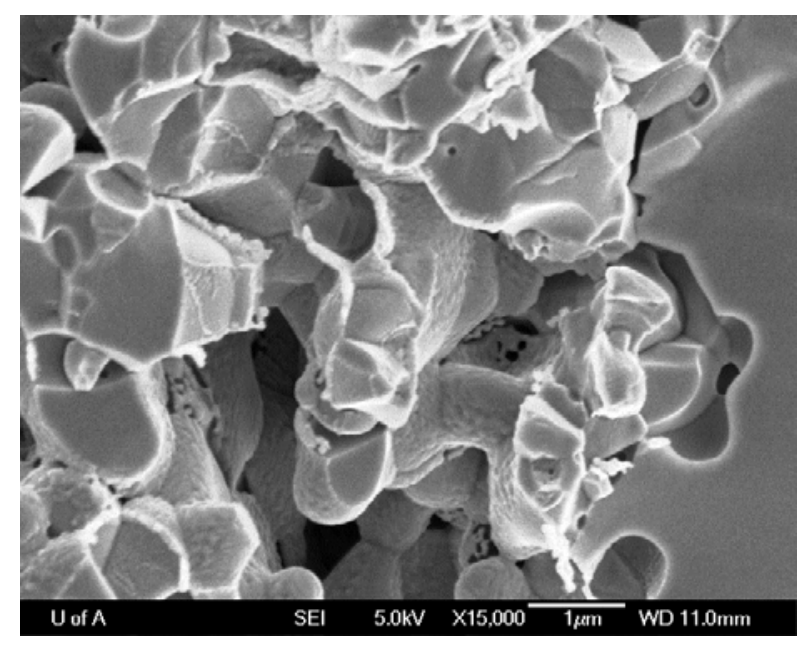

c

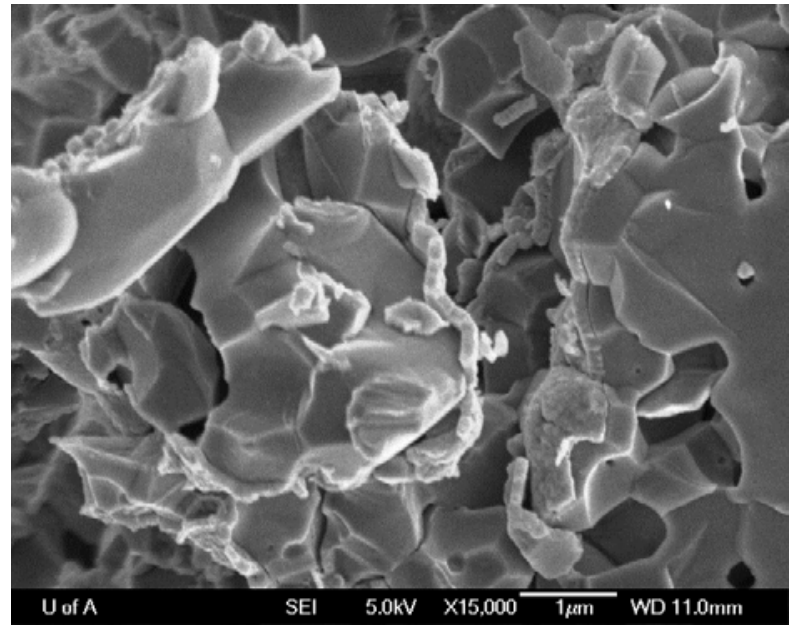

B

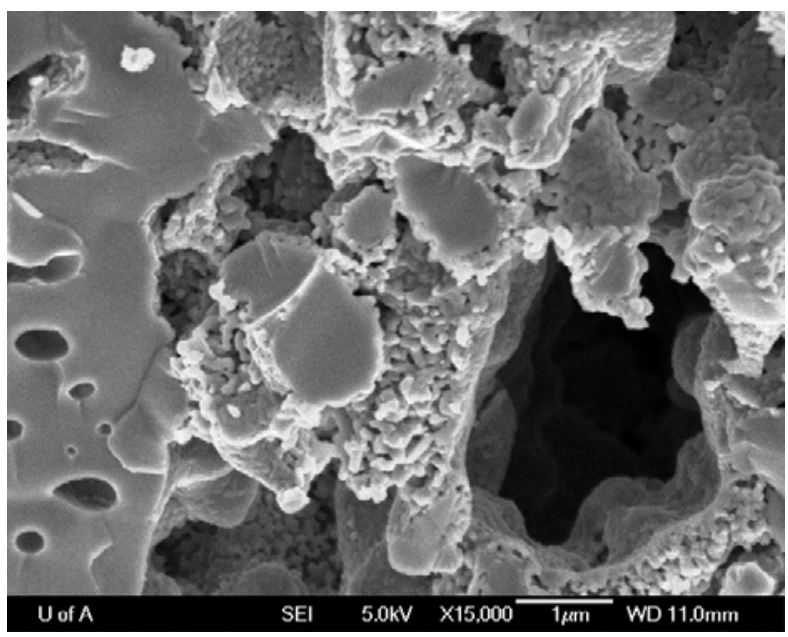

d

Figure 5 (a-d). 
Table 1.

\begin{tabular}{|c|c|c|c|c|c|c|}
\hline Tube & $\begin{array}{c}\mathrm{H}_{2} \mathrm{O} / \mathrm{H}_{2} \\
\text { ratio }\end{array}$ & $\begin{array}{c}\text { Temp } \\
\left({ }^{\circ} \mathrm{C}\right)\end{array}$ & $\begin{array}{c}\text { OCV } \\
(\mathrm{V})\end{array}$ & $\begin{array}{c}\text { Current } \\
\text { density at } \\
1.3 \mathrm{~V} \\
\left(\mathrm{Acm}^{-2}\right)\end{array}$ & $\begin{array}{c}\text { ASR } \\
\text { SOEC } \\
\left(\Omega \mathrm{cm}^{2}\right)\end{array}$ & $\begin{array}{c}\text { ASR } \\
\text { SOFC } \\
\left(\Omega \mathrm{cm}^{2}\right)\end{array}$ \\
\hline 1 & $50 / 50$ & 750 & 0.915 & -334 & $1.083(9)$ & - \\
\hline 1 & $50 / 50$ & 800 & 0.903 & -780 & $0.494(7)$ & - \\
\hline 1 & $30 / 70$ & 800 & 0.946 & -605 & 0.654 & $0.602(9)$ \\
\hline 1 & $3 / 97$ & 800 & 1.008 & -283 & $0.647(8)$ & $0.696(7)$ \\
\hline 1 & $50 / 50$ & 850 & 0.889 & -1098 & $0.392(9)$ & - \\
\hline 2 & $50 / 50$ & 700 & 0.954 & -450 & $0.743(5)$ & $1.384(6)$ \\
\hline 2 & $50 / 50$ & 750 & 0.923 & -668 & $0.539(5)$ & $1.005(4)$ \\
\hline 2 & $50 / 50$ & 800 & 0.907 & -842 & $0.485(3)$ & $0.749(5)$ \\
\hline 2 & $50 / 50$ & 850 & 0.889 & -1093 & $0.389(3)$ & $0.580(5)$ \\
\hline 2 & $50 / 50$ & 900 & 0.859 & -1453 & $0.288(4)$ & $0.426(6)$ \\
\hline
\end{tabular}

Table 2.

\begin{tabular}{|c|c|c|c|c|c|c|}
\hline Tube & $\begin{array}{c}\text { Temp } \\
\left({ }^{\circ} \mathrm{C}\right)\end{array}$ & $\begin{array}{c}\mathrm{R}_{\mathrm{e}} \\
\left(\Omega \mathrm{cm}^{2}\right)\end{array}$ & $\begin{array}{c}\mathrm{R}_{1} \\
\left(\Omega \mathrm{cm}^{2}\right)\end{array}$ & $\begin{array}{c}\mathrm{R}_{2} \\
\left(\Omega \mathrm{cm}^{2}\right)\end{array}$ & $\begin{array}{c}\mathrm{R}_{3} \\
\left(\Omega \mathrm{cm}^{2}\right)\end{array}$ & $\begin{array}{c}\text { ASR } \\
\left(\Omega \mathrm{cm}^{2}\right)\end{array}$ \\
\hline 1 & 750 & $0.173(1)$ & $0.180(3)$ & $0.206(19)$ & $0.423(12)$ & $0.982(35)$ \\
\hline 1 & 800 & $0.145(4)$ & $0.186(7)$ & $0.080(9)$ & - & $0.411(20)$ \\
\hline 1 & 850 & $0.136(3)$ & $0.143(8)$ & $0.050(9)$ & - & $0.329(20)$ \\
\hline 2 & 750 & $0.170(8)$ & $0.156(6)$ & $0.193(7)$ & $0.028(8)$ & $0.547(29)$ \\
\hline 2 & 800 & $0.147(2)$ & $0.167(5)$ & $0.140(6)$ & - & $0.454(13)$ \\
\hline 2 & 850 & $0.137(6)$ & $0.120(8)$ & $0.114(4)$ & - & $0.371(18)$ \\
\hline
\end{tabular}

